\title{
Application of magnetically treated water during initial growth of bell pepper seedlings
}

\author{
Aplicación de agua tratada magnéticamente \\ en el crecimiento inicial de las plantas de pimiento
}

\author{
Marcelo Zolin Lorenzoni ${ }^{1 *}$, Roberto Rezende ${ }^{2}$, Cássio de Castro Seron ${ }^{3}$, \\ Álvaro Henrique Cândido de Souza ${ }^{1}$
}

\begin{abstract}
The cultivation of bell peppers, before transplanting, starts in nurseries to obtain uniform and vigorous seedlings. This study aimed to evaluate the effect of applying magnetically treated water on germination and the initial growth of bell pepper seedlings. Two experiments were conducted from August to October 2018 in a protected environment at the Irrigation Tecnic Center (CTI/ UEM) - Maringá, Paraná: the first in 50-cell polyethylene trays and the second in plastic containers (180 ml). Both experiments were filled with a commercial substrate $(\mathrm{Su})$ and commercial substrate + soil mix (SS). The substrate was irrigated daily for the germination test, according to the corresponding treatment, and germination was quantified in the first 15 days after emergence to obtain the germination percentage and the final emerged percentage. Seedling growth was evaluated based on the following criteria at 43 days after sowing: height, stem diameter, total fresh mass, total dry mass, chlorophyll A and B, and carotenoids. The results showed that the application of magnetically treated water to seeds promoted germination one day prior to those irrigated without treatment when cultivated with SS. There was significant interaction for the chlorophyll A, with a $42 \%$ increase in SS cultivation with the application of magnetically treated water compared to the application of non-treated water. For the other variables, there were significant responses only in SS cultivation. Application of magnetically treated water caused higher gravimetric humidity in three out of ten evaluations, showing a significant reduction of evaporation in Su and SS cultivation.
\end{abstract}

Keywords: magnetic field, Capsicum annuum L., germination, magnetism, seeds.

\section{RESUMEN}

El cultivo de pimiento se inicia con la siembra en almácigos para obtener plántulas uniformes y vigorosas. El objetivo de este estudio fue evaluar el efecto de la aplicación de agua tratada magnéticamente sobre la germinación y el crecimiento inicial de plántulas de pimiento. Se realizaron dos experimentos en un ambiente protegido en el Centro Técnico de Irrigación (CTI / UEM) Maringá, Paraná, durante agosto a octubre de 2018. En el primer experimento se utilizaron bandejas de polietileno de 50 celdas y el segundo experimento se utilizaron envases de plástico $(180 \mathrm{~mL})$. En ambos experimentos se utilizaron dos tipos de sustrato, uno comercial (Su) y otro, con una mezcla de sustrato comercial + suelo (SS). Para la prueba de germinación, el sustrato se regó diariamente de acuerdo con el tratamiento. La germinación se cuantificó en los primeros 15 días después de la emergencia para obtener el porcentaje de germinación. Los parámetros medidos a los 43 días después de la siembra fueron: altura, diámetro del tallo, peso fresco total, peso seco seca total, clorofila A y B y carotenoides. Los resultados mostraron que la aplicación de agua tratada magnéticamente estimuló la germinación de las semillas un día antes de las que se regaron sin tratamiento cuando se cultivaron con SS. Hubo una interacción significativa para la clorofila A, con un aumento del $42 \%$ en el cultivo de SS con la aplicación de agua tratada magnéticamente en comparación con la aplicación de agua no tratada. Para las otras variables, hubo respuestas significativas solo en el cultivo de SS. La aplicación de agua tratada magnéticamente provocó una mayor humedad gravimétrica en tres de cada diez evaluaciones, mostrando una reducción significativa de la evaporación en el cultivo de Su y SS.

Palabras clave: campo magnético, Capsicum annuum L., germinación, magnetismo, semillas.

1 Instituto Federal Goiano. Posse, GO, Brazil.

2 Universidade Estadual de Maringá. Maringá, PR, Brazil.

3 Universidade Estadual de Mato Grosso do Sul. Cassilândia, MS, Brazil.

* Corresponding author: marcelo.lorenzoni@ifgoiano.edu.br

Fecha de Recepción: 19 de noviembre, 2019.

Fecha de Aceptación: 15 de noviembre, 2020. 


\section{Introduction}

The bell pepper stands out among the members of the family Solanaceae as it is cultivated in various parts of the world. In Brazil, it is among the 10 most important vegetables of economic and social importance (LORENZONI et al., 2016). The cultivation of this species starts in nurseries by sowing seeds in trays to obtain vigorous seedlings for transplantation, this being essential to obtain uniform germination. Seed germination rate is an significant parameter to evaluate initial seedling growth.

The adoption of new technologies and advanced techniques that promote increased horticultural production with less use of resources and input has been the objective of several studies over the years (Prohens and Nuez, 2008). The use of diseaseresistant hybrid seeds, cultivation in a protected environment, and irrigation with magnetically treated water have been some of the technologies used to provide competitive and sustainable food production.

The use of magnetically treated water for seed irrigation may be a promising tool in the future to improve agricultural production ecologically, as it requires no energy and is inexpensive (Silva and Dobránszki, 2014). This technique has been used in vegetables and been caused rapid germination and healthy development of the root system, ensuring more vigorous plants and a higher growth rate (Aguilera and Martín, 2016; Mridha et al., 2016).

Aguilera and Martín (2016) found that magnetically treated water accelerated the germination process of tomato seeds, making it a valuable technology for improving seedling quality. According to Zúñiga et al. (2016), this technology significantly effects on seed germination, as it is related to increased water absorption and enzyme activity during germination.

According to Maheshwari and Grewal (2009), it is necessary to elaborate specific studies on magnetism because the application of this technology involves various experimental conditions, such as exposure time and induction level, varying frequencies and intensities, and type of magnetic field.

This study aimed to evaluate the application of magnetically treated water during germination and initial growth of Magali $\mathrm{R}$ hybrid seedlings (bell pepper) and was conducted in a protected environment under two cultivation conditions (commercial substrate and substrate + soil).

\section{Materials and methods}

The experiment was carried out in a protected environment at the Centro Técnico de Irrigação (CTI) from Universidade Estadual de Maringá (UEM) in the municipality of Maringá - PR, (23⒉ $5^{\prime} 57^{\prime}$ 'S, $51^{\circ} 57^{\prime} 08^{\prime} \mathrm{W}$ ) at an altitude of $542 \mathrm{~m}$. According to the Köppen classification, the region's climate is Cfa, humid mesothermal (ALVARES et al., 2013). Two experiments were conducted from August to October 2018: in the first experiment, 50-cell polyethylene trays were used to evaluate seedling germination, and in the second, $180 \mathrm{ml}$ plastic containers (upper diameter $7 \mathrm{~cm}$, lower diameter $4.5 \mathrm{~cm}$, and height $7.8 \mathrm{~cm}$ ) to evaluate seedling growth. Temperatures were recorded during the experimental period in an automatic weather station installed inside the protected environment. The maximum temperature ranged from 19.5 to $41.8^{\circ} \mathrm{C}$, the average from 13.5 to $29.1{ }^{\circ} \mathrm{C}$, and the minimum, from 6.3 to $21{ }^{\circ} \mathrm{C}$ throughout the experimental period (Figure 1).

According to Filgueira (2003), for the production of bell pepper seedlings, the temperature should vary between 26 and $30^{\circ} \mathrm{C}$, whereas temperatures less than $15^{\circ} \mathrm{C}$ or greater than $35^{\circ} \mathrm{C}$ can damage the early stages of culture. During the experiment, temperatures beyond the recommended range were recorded, These variations occurred at short intervals during the day and night without damage to the crop.

The soil used, Dystroferric Red Clayey Nitosol (Embrapa, 2013), was sieved for homogenization and had the following chemical characteristics: $\mathrm{P}=2.82 \mathrm{mg} \mathrm{dm}{ }^{-3} ; \mathrm{K}^{+}=0.08 \mathrm{cmol}_{\mathrm{c}} \mathrm{dm}^{-3} ; \mathrm{Ca}^{2+}=$

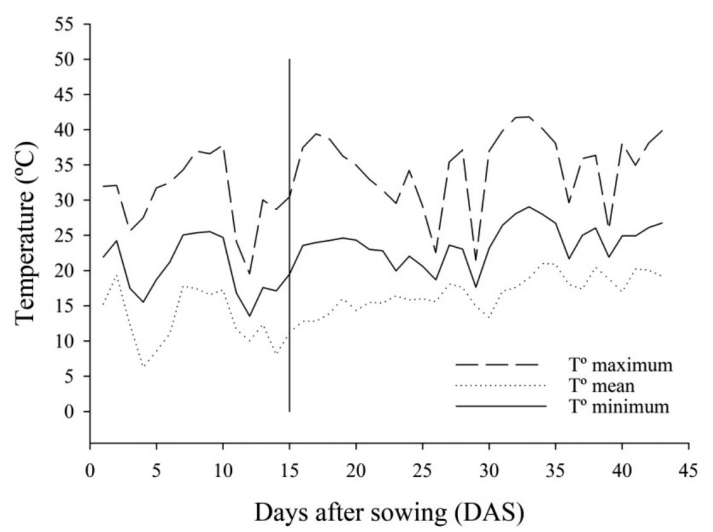

Figure 1. Maximum, average and minimum temperature recorded daily inside the protected environment during the trial period. 
$1.11 \mathrm{cmol}_{\mathrm{c}} \mathrm{dm}^{-3} ; \mathrm{Mg}^{2+}=1.05 \mathrm{cmol}_{\mathrm{c}} \mathrm{dm}^{-3} ; \mathrm{Al}^{3+}$ $=0.45 \mathrm{cmol}_{\mathrm{c}} \mathrm{dm}^{-3} ; \mathrm{H}^{+}=4.33 \mathrm{cmol}_{\mathrm{c}} \mathrm{dm}^{-3} ; \mathrm{Na}^{+}=$ $9.35 \mathrm{mg} \mathrm{dm}^{-3}$ e M.O. $=9.86 \mathrm{~g} \mathrm{dm}^{-3}$. Liming was performed at $1.5 \mathrm{~g} \mathrm{~kg}^{-1}$ of soil 60 days before sowing. The commercial substrate (Mecplant) used is composed of pine bark, vermiculite, acidity concealer, and macronutrients.

A Sylocimol Residence (Timol) magnetizer was used to obtain magnetically treated water, capable of magnetically treating 1,000 L of water in $1 \mathrm{~h}$.The machine is composed of alternating magnets protected by a stainless steel cylinder (diameter $10 \mathrm{~cm}$ and height $16.5 \mathrm{~cm}$ ) and features a 1000 Gauss magnetic field, evaluated in the physics department of UEM, with a gaussmeter (LakeShore 425 Gaussmeter). The equipment was placed in the reservoir's center. From there, water was drawn for irrigation and remained there throughout the experiment.

A completely randomized design in a $2 \times 2$ factorial scheme was adopted for the first experiment, resulting in four treatments with six repetitions. The first factor was irrigation with and without magnetically treated water, and the second factor was the cultivation condition, which varied according to how the trays were filled with commercial substrate: $(100 \%$ v.) $(\mathrm{Su})$, commercial substrate $\operatorname{mix}(50 \%$ v.), and soil (50\% v.) (SS).

Twelve trays were filled with Su only, and 12 trays were filled with SS, with all cells being filled completely. A Magali R. bell pepper hybrid seed was deposited in each cell. After sowing, the trays were irrigated according to the corresponding treatment, taken to the protected environment, and placed on benches $1.0 \mathrm{~m}$ high. The trays were irrigated each morning using a watering can.

After emerging, germinated seedlings in the tray cells were quantified daily, and the germination percentage (GP) for both treatments was calculated. The seedlings were quantified within the first 15 days after emergence. The final percentage emerged (FPE) was determined by dividing the total of seedlings emerged by the total number of seeds and multiplying by 100 to obtain the percentage value (\%).

In the second experiment, the same design was adopted, and the same factorial scheme, with four treatments and six repetitions. Seeds of the same bell pepper hybrid were sown, placing one seed per experimental plot (plastic container), transferred to the protected environment, and placed on benches, where they remained until the end of the experiment.
Plastic containers were drilled at the base with 12 holes for water drainage. Prior to filling, the substrate and soil were oven-dried at $105{ }^{\circ} \mathrm{C}$ for 48 hours. The containers were filled with $46 \mathrm{~g}$ of a dry substrate $(100 \%$ v.) for those that contained only this material, and with $58 \mathrm{~g}$ of dry soil (50\% v.) and $22 \mathrm{~g}$ of a dry substrate $(50 \% \mathrm{v}$.) for those that contained the SS mixture. A digital scale was used for the measurements to ensure uniform weight in all containers.

The containers were placed in a tray with water so that saturation occurred by capillarity to determine maximum retention humidity.After $24 \mathrm{~h}$, the containers were removed from the tray, weighed on precision scales $(1,0 \mathrm{~g})$, and sealed to prevent evaporation. After this process, they were left at rest to drain freely and weighed at $1 \mathrm{~h}$ intervals for $12 \mathrm{~h}$. The maximum humidity retained was determined by the average of the three cups for each of the materials used for filling. The averages were $1.4 \mathrm{~g} \mathrm{~g}^{-1}$ for the substrate and $0.7 \mathrm{~g} \mathrm{~g}^{-1}$ for substrate + soil.

The replacement of water in the seedling containers was performed daily, in the morning. The plastic containers were placed on a digital scale (precision $2 \mathrm{~g}$ ) to get the current mass and subsequently irrigated with the measured humidity being raised to the maximum humidity retention value, according to the corresponding treatment, using a syringe.

The variation in gravimetric humidity in plastic containers, with the application of magnetically treated water in Su and SS, was measured within the first 10 days after sowing to ensure higher reliability because the mass accumulation of bell pepper seedlings could interfere with weighing. The seedlings with six permanent leaves were removed close to the ground surface at 43 days after sowing, and the following characteristics were evaluated: plant height (HP) in $\mathrm{cm}$, stem diameter (SD) in $\mathrm{mm}$, total fresh mass (TFM), and total dry mass (TDM) in $\mathrm{g}$, chlorophyll $\mathrm{A}$, chlorophyll $\mathrm{B}$, and carotenoid in $\mu \mathrm{g} \mathrm{ml}^{-1}$.

HP and SD measurements were estimated using a ruler and a digital caliper, respectively. After cutting, the seedlings were weighed on a digital scale (accuracy $0.001 \mathrm{~g}$ ) to get the TFM, placed in labeled paper bags, and brought into the forced-circulation greenhouse at $65^{\circ} \mathrm{C}$, where they remained until a constant mass was obtained. After this period, they were weighed on a digital scale to obtain the TDM. 
To obtain chlorophyll, we used the Arnon methodology (1949) adapted by Lichtenthaler (1987) by pulling out two leaf discs (two $\mathrm{mm}$ in diameter) from each plant and placing them in amber glass bottles containing $5 \mathrm{ml}$ of $80 \%$ acetone. The bottles were covered with aluminum foil and taken to the greenhouse biochemical oxygen demand incubator, where they remained in the dark at $25^{\circ} \mathrm{C}$ for 7 days. After this period, spectrophotometer readings were taken at $663 \mathrm{~nm}, 645 \mathrm{~nm}$, and $470 \mathrm{~nm}$. The data obtained were submitted to analysis of variance, and subsequently, Tukey's test was applied at the 5\% probability level. Analyses were performed using Sisvar software (Ferreira, 2014).

\section{Results and discussion}

Figure 2 shows the percentage of bell pepper seed germination by applying magnetically treated water and non-treated water in substrate-filled trays (Figure 2A) and substrate + soil mix (Figure 2B).

Germination started 10 days after sowing under both cultivation conditions; however, in trays filled with substrate only (Figure 2A), the percentage of seeds that germinated at the beginning was higher with the application of non-magnetized water. Germination under both conditions (with and without treatment) started the same day; however, the number of seeds that germinated with the application of non-magnetized water was higher until 20 days after sowing. At that point, the maximum germination percentage had been reached and remained constant following the application of magnetically treated water and non-treated water. The number of seeds germinated with the application of magnetized water was larger. In trays filled with substrate + soil mix (Figure 2B), germination of seeds irrigated with magnetized water first began at 10 days after sowing, while those irrigated with non-treated water started the next day at 11 days after sowing.

In an experiment by Mahmood and Usman (2014), they observed that germination of corn seeds sown in washed sand began 2 days earlier with the application of magnetically treated water compared to non-treated water. Aguilera and Martín (2016) verified that the application of magnetically treated led to early germination of tomato seeds grown in a mixture of peat, zeolite, and organic matter. Germination began 2 days earlier in the treatment with magnetically treated water than non-treated water method.

Under the cultivation condition with substrate + soil, the bell pepper seeds reached the maximum germination percentage faster (at 17 days after sowing) when compared to the cultivation condition with substrate only. This faster germination could be attributed could be attributed to the addition of soil in the substrate for growing bell pepper seedlings. Additionally, in a study by Surendran et al. (2016), soil retained more water when irrigated with magnetically treated water, benefiting the germination of eggplant seedlings in their study. Maheshwari and Grewal (2009) found that
A.

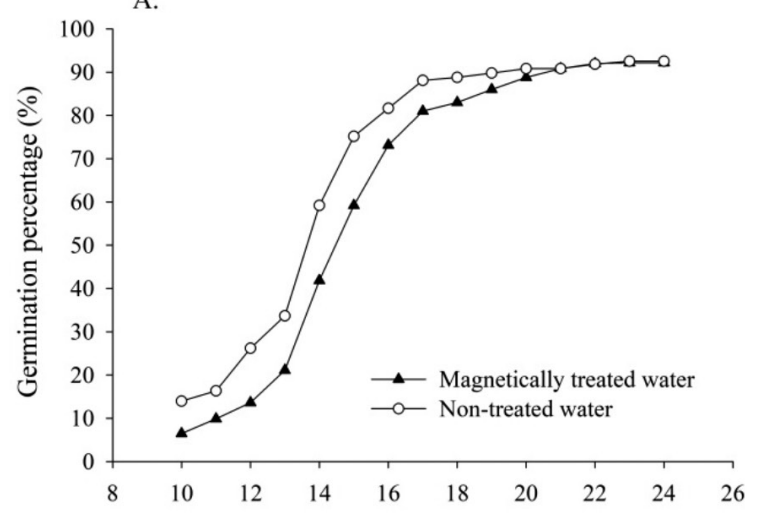

B.

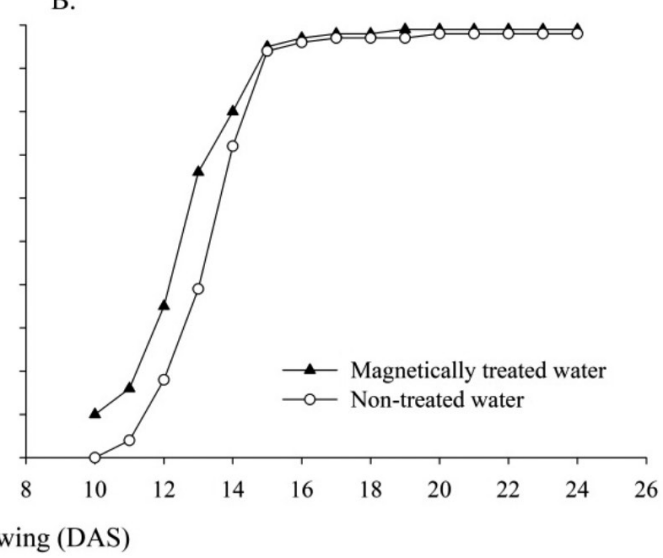

Figure 2. Germination percentage of bell pepper seeds with magnetically treated water application and non-treated water. Trays filled with commercial substrate (A) and trays filled with substrate + soil mix (B). 
magnetically treated water stimulated germination by promoting faster metabolic processes inside the seeds.

In the present study, a significant difference was found in the final percentage that emerged (FPE) between the cultivation conditions, with average values of $91.5 \%$ for $\mathrm{Su}$ and $97.6 \%$ for the SS; however, the water treatment factor showed no significant differences (Table 1). Similar results were obtained by Grewal and Maheshwari (2011) by application of magnetically treated water to pea and chickpea seeds. Significant differences in FPE by applying magnetically treated water were verified by Aguilera and Martín (2016), with a 36\% growth increment for tomato seedlings.

For the second experiment, a significant interaction was found for the chlorophyll variable A. There was an isolated effect between the cultivation conditions (Su and SS) for all variables analyzed $(p \leq 0.05)$ in the bell pepper seedlings. There were no significant differences for the factor of irrigation water with magnetic treatment and non-treated water (Table 1). The results are presented for the variables HP and SD using the Tukey's test at 5\% significance, showing a significant increment in the variables when cultivated in the substrate + soil mixture (Figure 3).

There was an increase of $54.5 \%$ in HP and $33.7 \%$ in SD of bell pepper seedlings grown in the substrate + soil mixture compared to cultivation with substrate only. No significant differences were found in favor of magnetic water treatment, although the mean values of these variables were higher for seedlings that received magnetically treated water. Aguilera and Martín (2016) found statistical differences with the application of

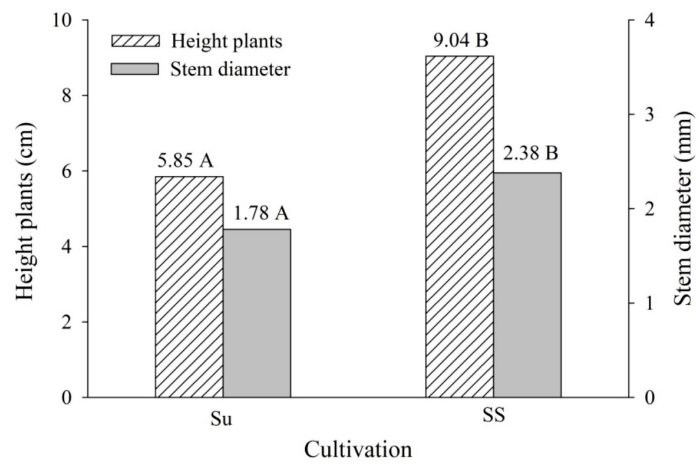

Figure 3. Average values of height plant and stem diameter for bell pepper seedlings grown in substrate $(\mathrm{Su})$ and substrate + soil (SS). Letters differ statistically by Tukey test at $5 \%$ probability.

magnetically treated water on tomato seedlings, with an increase of $97 \%$ for plant height and $12 \%$ for stem diameter. For TFM and TDM (Figure 4A), there was an increase of $>120 \%$ in the average values of seedlings grown in substrate + soil. The addition of soil in the substrate for bell pepper cultivation may have contributed to greater mass accumulation in seedlings because the soil holds more water than the substrate (Surendran et al., 2016).

Sayed (2014) obtained significant increases in growth parameters (plant height, leaf, stem, and root dry weight, and leaf area) of bean seeds irrigated with magnetically treated water compared to non-treated water; these results differ from those of the present study. Souza et al. (2005) verified significant differences in these same variables in tomato cultivation under a magnetic field. According to Ospina-Salazar et al. (2018), the lack of significant responses to magnetically treated water demonstrates that not all species show similar responses when subjected to this condition.

Table 1. Analysis of variance analysis for final percentage emerged (FPE), height plant (HP), stem diameter (SD), total fresh mass (TFM), total dry mass (TDM), Chlorophyll A, Chlorophyll B and carotenoids of bell pepper seedlings irrigated with magnetic treatment water and non-treated water.

\begin{tabular}{lccccccccc}
\hline \multirow{2}{*}{ Source variation } & \multicolumn{9}{c}{ Mean squares } \\
\cline { 2 - 10 } & DF & FPE & HP & SD & TFM & TDM & Chlo A & Chlo B & Carot \\
\hline Water Treat. (T) & 1 & $0.0002^{\text {ns }}$ & $0.101^{\text {ns }}$ & $0.034^{\text {ns }}$ & $0.006^{\text {ns }}$ & $0.001^{\text {ns }}$ & $0.368^{\text {ns }}$ & $0.004^{\text {ns }}$ & $0.021^{\text {ns }}$ \\
Cultivation (C) & 1 & $228.29^{*}$ & $61.05^{*}$ & $2.13^{*}$ & $4.829^{*}$ & $0.084^{*}$ & $13.47^{*}$ & $0.920^{*}$ & $1.188^{*}$ \\
T x C & 1 & $2.720^{\text {ns }}$ & $0.264^{\text {ns }}$ & $0.013^{\text {ns }}$ & $0.004^{\text {ns }}$ & $0.001^{\text {ns }}$ & $1.312^{*}$ & $0.040^{\text {ns }}$ & $0.052^{\text {ns }}$ \\
Error & 20 & 13.598 & 0.667 & 0.028 & 0.040 & 0.001 & 0.186 & 0.017 & 0.014 \\
CV $(\%)$ & & 3.90 & 10.96 & 8.04 & 18.38 & 32.22 & 12.79 & 13.32 & 9.55 \\
Mean & & 94.58 & 7.44 & 2.08 & 1.088 & 0.127 & 3.378 & 0.999 & 1.267 \\
\hline
\end{tabular}

\footnotetext{
* Significant at 0.05 probability level; ns not significant by $\mathrm{F}$ test.
} 
A.

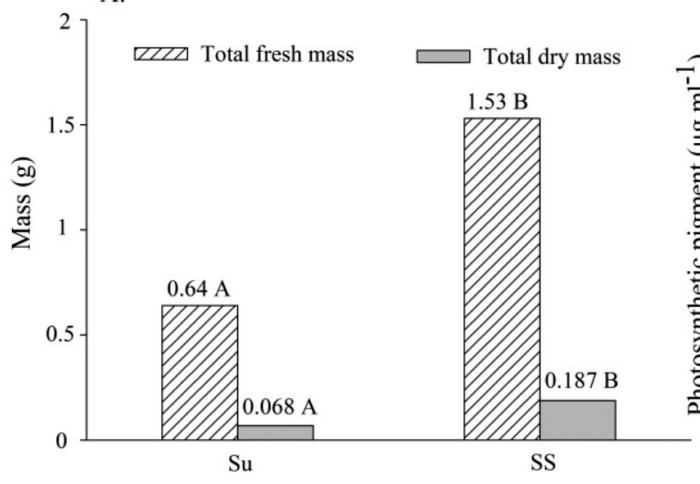

B.

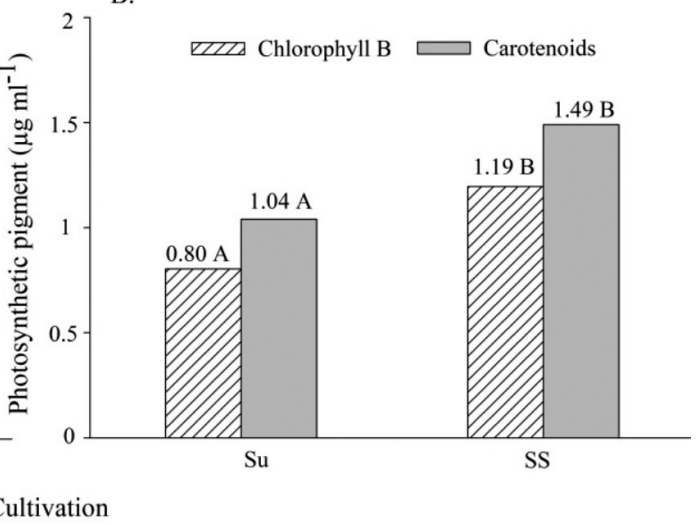

Figure 4. Average values of total fresh mass and total dry mass (A) and chlorophyll B and carotenoids (B) for bell pepper seedlings grown on substrate (Su) and substrate + soil (SS). Letters differ statistically by Tukey test at $5 \%$ probability.

Are verified in Figure 4B, Chlorophyll B and carotenoids showed average increases of $48.8 \%$ and $43.3 \%$, respectively, when grown in the substrate + soil mixture. In Table 2, Tukey's test mean values for the interaction between factors are presented as follows. It is remarkable that the Chlorophyll A presented significant differences and increasing averages by application of magnetically treated water, the substrate + soil being superior to cultivation with substrate only. The application of magnetically treated water affected this variable when grown on substrate + soil, as shown by a $42 \%$ increase compared to the application of non-treated water.

According to Taiz and Zeiger (2009), chlorophylls play an important role in photosynthesis and plant growth because they are responsible for capturing light energy; chlorophyll A being the main pigment of light collecting complexes for photochemical reactions. According to Al-Khazan et al. (2011),

Table 2. Chlorophyll A average values of bell pepper seedlings irrigated with water with and without magnetic treatment cultivated in substrate and substrate + soil.

\begin{tabular}{llr} 
Variable & \multicolumn{2}{c}{ Chlorophyll A $\left(\mu \mathrm{g} \mathrm{ml}^{-1}\right)$} \\
\hline \multirow{2}{*}{ Cultivation } & \multicolumn{2}{c}{ Magnetic treatment water } \\
\cline { 2 - 3 } & Non-treated & Treated \\
\hline Substrate & $2.27 \mathrm{Aa}$ & $2.98 \mathrm{Ab}$ \\
\hline Substrate + soil & $4.01 \mathrm{Ba}$ & $4.23 \mathrm{Ba}$ \\
\hline
\end{tabular}

* Means followed by the same letter do not differ statistically, uppercase in the column and lowercase in the row, by Tukey test at 0.05 probability level. water scarcity can decrease these pigments and may lead to decreased photosynthetic efficiency and affect other cellular processes. Carotenoids are essential for protecting the photosynthetic apparatus against singlet oxygen that can damage many cellular components such as lipids (Taiz and Zeiger, 2009).

Hozayn and Qados (2010) found a significant increase in photosynthetic pigments (Chlorophyll A, Chlorophyll B, and carotenoids) with the application of magnetically treated water compared to the application of non-treated water on wheat crops. Al-Khazan et al. (2011) obtained an increase in the yield of Chlorophyll A, Chlorophyll B, and Carotenoids with the application of magnetically treated water on the native desert bush (jojoba). The results presented by Sayed (2014) indicated that irrigation with magnetically treated water significantly increased chlorophyll A, chlorophyll $\mathrm{B}$, and carotenoids in fava beans.

The non-significance of variables with the application of water with magnetic treatment reinforces the idea of Ospina-Salazar et al. (2018), which states that not all vegetables react in the same manner when irrigated with magnetically treated water. The intensity of the magnetic field, exposure time, and growing conditions vary from one crop to another. Figure 5 presents the variation of gravimetric humidity inside the containers during the first 10 days after sowing, using treated and untreated water. The first significant difference occurred in the first replacement of magnetically treated water on crops in $\mathrm{Su}$ (Figure 5A) and SS (Figure 5B). 


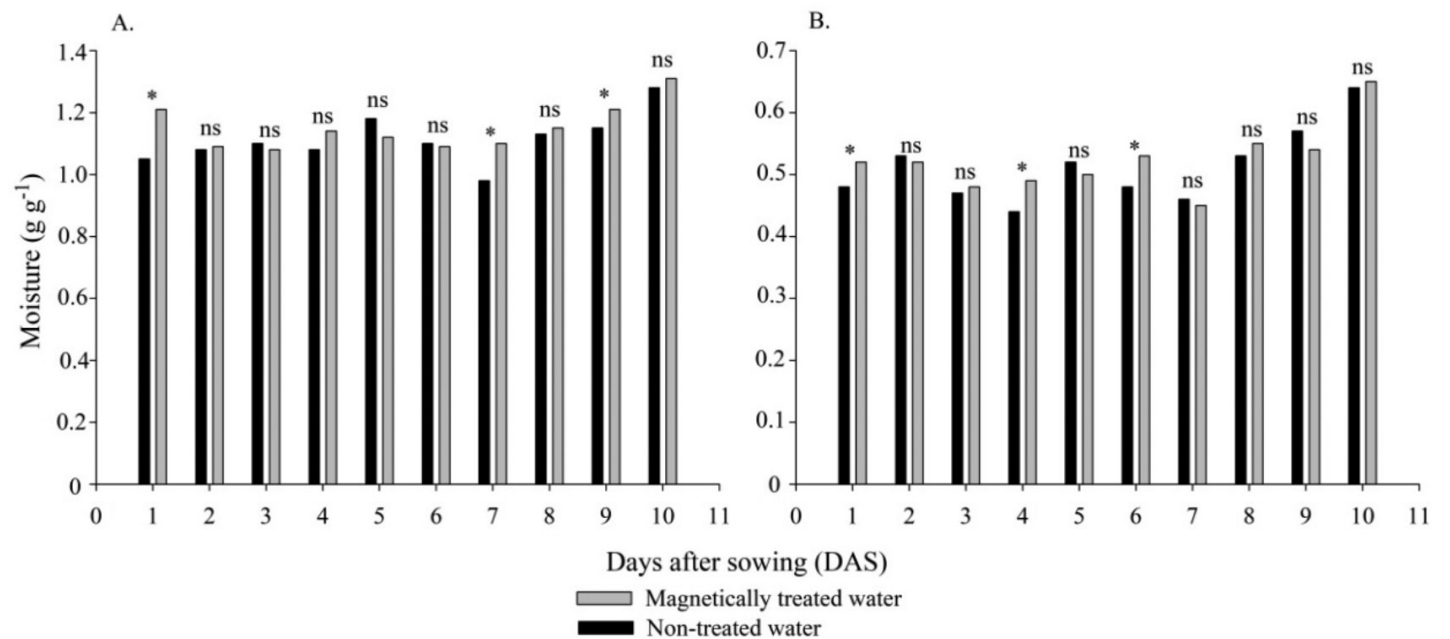

Figure 5. Moisture in plastic containers in the first ten days after sowing the bell peppers with application of magnetically treated water when grown on substrate (A) and substrate + soil mix (B).

* Significant at 0.05 probability level; ${ }^{\text {ns }}$ not significant by $\mathrm{F}$ test.

Among the 10 evaluations carried out, three presented significant differences for each cultivation condition (Su and SS), demonstrating that the magnetically treated water led to higher gravimetric humidity in the three evaluations. The variation in gravimetric humidity in plastic containers may be related to the evaporation rate or changes in water properties caused by magnetic or soil treatment.

Several theories have been proposed in the literature to explain the interactions between magnetically treated water, minerals, and soil particles. According to Khoshravesh et al. (2011), in the magnetization process, the water molecules react with the ions in the hydrogen bonds to become more cohesive to the environment, facilitating their attachment to soil particles, penetrating the soil micropores, and preventing percolation to lower depths.

Zuñiga et al. (2016) claimed that the effects of magnetic water treatment on soil are related to the greater movement of various ions in the soil solution, and changes in soil profile moisture. In a study by Surendran et al. (2016), higher soil water retention was observed when irrigated with magnetically treated water in eggplant culture. The authors found statistical differences in soil moisture measured on the first and second days after irrigation with magnetically treated water, attributing the reduction in soil moisture to increased water cohesion in soil particles.

\section{Conclusions}

1. Magnetic treatment of water alters its characteristics. Significant differences were found in the two experiments performed, with significant interaction for the Chlorophyll A in both cultivation forms.

2. Bell pepper seeds reached the highest germination percentage faster when subjected to water with magnetic treatment in SS-filled trays.

3. The variables FPE, HP, SD, TFM, TDM, Chlorophyll B, and carotenoids were significant for the cultivation conditions; the SS cultivation presented higher values.

4. Application of magnetically treated water resulted in significant evaporation reduction in three evaluations, showing higher gravimetric moisture in Su and SS cultivation when irrigated with magnetically treated water.

\section{Acknowledgements}

To the Postgraduate Program in Agronomy of the State University of Maringá and to the financial support by the Brazilian agency Coordenação de Aperfeiçoamento de Pessoal de Nível Superior (CAPES). 


\section{Literature Cited}

Aguilera, J.G.; Martín, R.M.

2016. Água tratada magneticamente estimula a germinação e desenvolvimento de mudas de Solanum lycopersicum L. Revista Brasileira de Agropecuária Sustentável, 6(1): 47-53.

Al-Khazan, M.; Abdullatif, B.; Al-Assaf, N.

2011. Effects of magnetically treated water on water status, chlorophyll pigments and some elements content of jojoba (Simmondsia chinensis L.) at different growth stages. African Journal of Environmental Science and Technology, 5(9): 722-731.

Alvares, C. A. Stape, J.L.; Sentelhas, P.C.; De Moraes Gonçalves, J.L.; Sparovek, G.

2013. Köppen's climate classification map for Brazil. Meteorologische Zeitschrift, 22(6): 711-728.

Arnon, D.I.

1949. Copper enzimas in isolated cloroplasts. Polyphenoloxidase in Beta Vulgaris. Plant Physiology, 24(1): 1-15.

Embrapa.

2013. Sistema brasileiro de classificação de solos. $3^{a}$ edição. Empresa Brasileira De Pesquisa Agropecuária - Centro Nacional de Pesquisa de Solos. Rio de Janeiro, Brazil. 353 p.

Ferreira, D.F.

2014. Sisvar: a Guide for its Bootstrap procedures in multiple comparisons. Ciência e Agrotecnologia, vol. 38, No 2, p. 109-112.

Filgueira, F.A.R.

2003. Solanáceas: agrotecnologia moderna na produção de tomate, batata, pimentão, pimenta, berinjela e jiló. UFLA. Lavras, Brazil. 333 p.

Grewal, H.S.; Maheshwari, B.L.

2011. Magnetic treatment of irrigation water and snow pea and chickpea seeds enhances early growth and nutrient contents of seedlings. Bioelectromagnetics, 32(1): 58-65.

Hozayn, M.; Qados, A.M.S.A.

2010. Magnetic water application for improving wheat (Triticum aestivum L.) crop production. Agriculture and Biology Journal of North America, 1(4): 677-682.

Khoshravesh, M.; Mostafazadeh-Fard, B.; Mousavi, S.F.; Kiani, A.R.

2011. Effects of magnetized water on the distribution pattern of soil water with respect to time in trickle irrigation. Soil Use and Management, 27 (1): 515-522.

Lichtenthaler, H.K.

1987. Chlorophylls and Carotenoids: Pigments of Photosynthetic Biomembranes, Methods in enzymology, 148: 350-382.
Lorenzoni, M.Z.; Rezende, R.; Cândido De Souza, A.; De

Castro Seron, C.; Hachmann, T.; Lourenço De Freitas, P.S.

2016. Response od bell pepper crop fertigated with nitrogen and potassium doses in protected environment. Agrotechnology, 5(3): 148.

Maheshwari, B.L.; Grewal, H.S.

2009. Magnetic treatment of irrigation water: Its effects on vegetable crop yield and water productivity. Agricultural Water Management, 96(1): 1229-1236.

Mahmood, S.; Usman, M.

2014. Consequences of magnetized water application maize seed emergence in sand culture. Journal of Agricultural Science and Technology, 16(1): 47-55.

Mirdha, N. Chattaraj, S.; Chakraborty, D.; Anand, A.; Aggarwal,

P.; Nagarajan, S.

2016. Pre-Sowing static magnetic field treatment for improving water and radiation use efficiency in Chickpea (Cicer arirtinum L.) under soil moisture stress. Bioelectromagnetics, 37(1): 400-408.

Ospina-Salazar, D.I. Benavides-Bolanos, J.A., Zuniga-Escobar,

O.; Munoz-P.

2018. Photosynthesis and biomass yield in Tabasco pepper, radish and maize subjected to magnetically treated water. Corpoica Ciencia Tecnologia Agropecuaria, 9(2): 307-321.

Prohens, J.; Nuez, F.

2008. Handbook of plant breeding, Vegetables II: Fabaceae, Liliaceae, Solanaceae and Umbelliferae. Springer. 365 p.

Sayed, H. E. S. A. E. 2014. Impacto f magnetic water irrigation for improve the rowth, chemical composition and yield production of Broad Bean (Vicia faba L.) plant. American Journal of Experimental Agriculture, 4(4): 476-496.

Silva, J.A.T. Da.

2014. Dobránszki, J. Impacto f magnetic water on plant growth.

Environmental and Experimental Biology, 12(1): 137-142.

Surendran, U.; Sandeep O.; Joseph E.J.

2016. The impacts of magnetic treatment of irrigation water on plant, water and soil characteristics. Agricultural Water Manegement, 178(1): 21-29.

Taiz, L.; Zeiger, E.

2009. Fisiologia Vegetal. $4^{\mathrm{a}}$ ed. Artmed, Porto Alegre. 820 p.

Zúñiga, O.; Benavides, J.; Ospina, D.; Jiménez, C.; Gutiérrez, M. 2016. Tratamiento magnético de agua de riego y semillas en agricultura. Ingeniería y Competitividad, 18(1): 217-232. 